This item was submitted to Loughborough's Research Repository by the author.

Items in Figshare are protected by copyright, with all rights reserved, unless otherwise indicated.

\title{
AC impedance characteristics of solid-state planar electrochemical carbon monoxide sensors with Nafion $®$ as solid polymer electrolyte
}

PLEASE CITE THE PUBLISHED VERSION

http://dx.doi.org/10.1016/S0013-4686(02)00275-X

PUBLISHER

(C) Elsevier Science

VERSION

AM (Accepted Manuscript)

LICENCE

CC BY-NC-ND 4.0

\section{REPOSITORY RECORD}

Mortimer, Roger J., and Alison Beech. 2019. "AC Impedance Characteristics of Solid-state Planar Electrochemical Carbon Monoxide Sensors with Nafion ${ }^{\circledR}$ as Solid Polymer Electrolyte”. figshare. https://hdl.handle.net/2134/11442. 
This item was submitted to Loughborough's Institutional Repository (https://dspace.lboro.ac.uk/) by the author and is made available under the following Creative Commons Licence conditions.

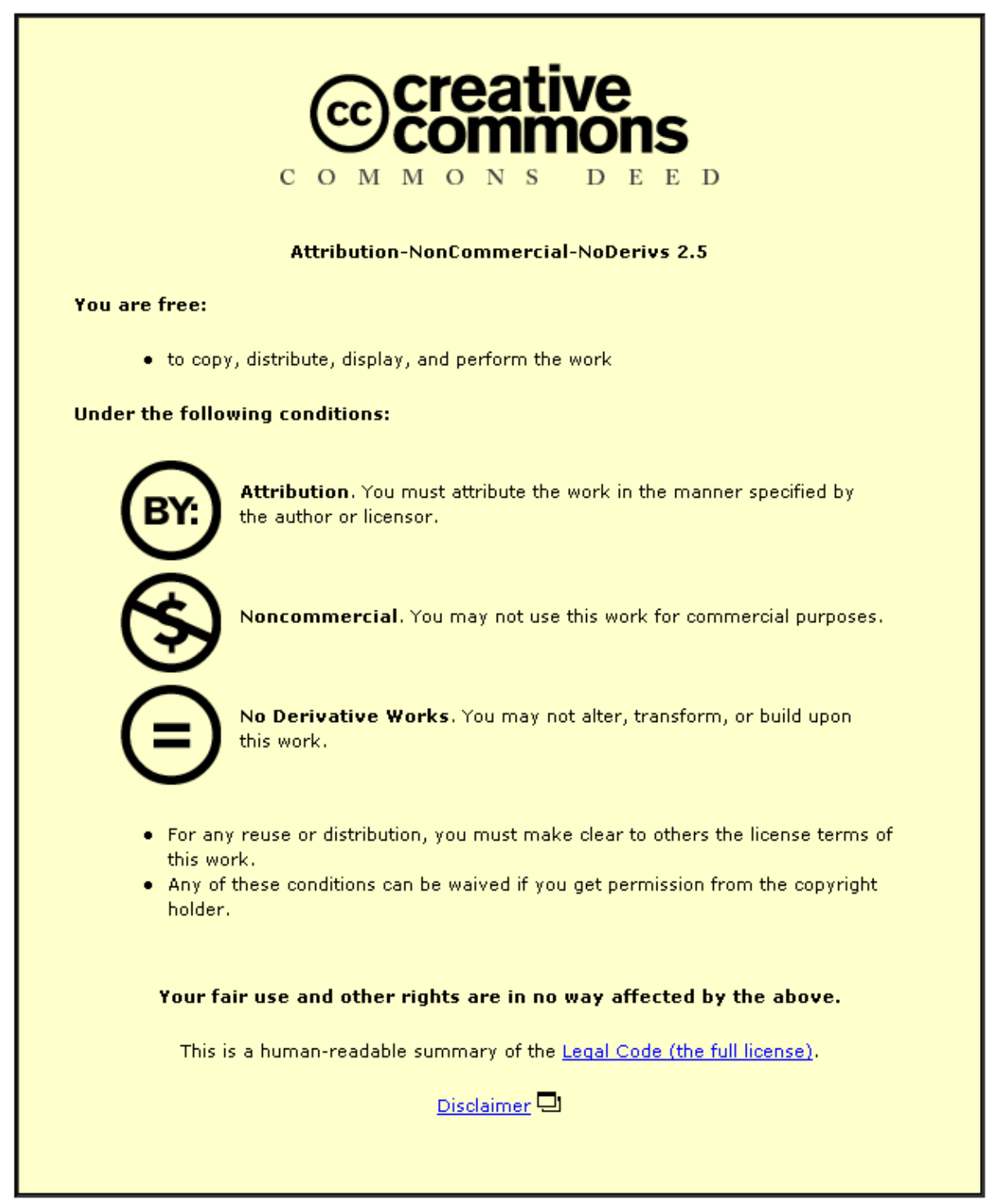

For the full text of this licence, please go to: http://creativecommons.org/licenses/by-nc-nd/2.5/ 
Submitted to Electrochimica Acta on 10 April 2002

Revised version 3 May 2002

Number of pages $=18$

Proofs to Dr R J Mortimer

Department of Chemistry,

Loughborough University,

Loughborough,

Leicestershire LE11 3TU, UK

Tel.: +44 (0)1509 222583

Fax: +44 (0)1509 223925

E-mail: R.J.Mortimer@lboro.ac.uk 
AC impedance characteristics of solid-state planar

electrochemical carbon monoxide sensors with Nafion ${ }^{\circledR}$ as solid polymer electrolyte

\author{
Roger J Mortimer*, Alison Beech \\ Department of Chemistry, \\ Loughborough University, \\ Loughborough,
}

Leicestershire LE11 3TU, UK 


\section{Abstract}

The AC impedance characteristics of planar solid-state electrochemical carbon monoxide (CO) sensors with Nafion ${ }^{\circledR}$ as the solid polymer electrolyte are reported. For a re-cast Nafion ${ }^{\circledR}$ sensor design, Nyquist plots indicated very high impedances $\left(10^{7}-10^{8} \Omega\right)$, which slightly decreased with an increase in the working electrode surface area $\left(0.25-0.50 \mathrm{~cm}^{2}\right)$. Only one enlarged semi-circle was observed, relating to an equivalent circuit with a geometrical capacitance $\left(C_{\mathrm{g}}\right)$ in parallel with a bulk resistance $\left(R_{\mathrm{b}}\right)$. In contrast, a sensor design using a commercial membrane produced a system with a much lower impedance (< $10^{3} \Omega$ ), with Nyquist plots showing a flattened semi-circle at high frequencies (due to $C_{\mathrm{g}}$ and $R_{\mathrm{b}}$ in parallel), followed by the start of a large semi-circle (due to the double-layer capacitance, $C_{\mathrm{dl}}$, in parallel with the charge-transfer resistance, $R_{\mathrm{ct}}$ ) over a lower frequency range. On addition of $\mathrm{CO}$, the second circular arc reduced in size, indicating that the interfacial impedance of the electrochemical system had decreased.

Keywords: carbon monoxide, sensor, Nafion ${ }^{\circledR}$, AC impedance 


\section{Introduction}

An amperometric planar solid-state room temperature carbon monoxide (CO) sensor has been reported [1-8], where fabrication involves solvent casting the perfluorosulphonate ionomer Nafion ${ }^{\circledR}$ onto working, counter and reference electrodes that are integrated on an alumina substrate. The sensor operates under fuel cell principles; CO is oxidised at the working electrode and ambient oxygen is reduced at the counter electrode.

Working electrode: $\quad 2 \mathrm{CO}+2 \mathrm{H}_{2} \mathrm{O}=2 \mathrm{CO}_{2}+4 \mathrm{H}^{+}+4 \mathrm{e}^{-}$

Counter electrode: $\quad \mathrm{O}_{2}+4 \mathrm{H}^{+}+4 \mathrm{e}^{-}=2 \mathrm{H}_{2} \mathrm{O}$

Cell reaction: $\quad 2 \mathrm{CO}+\mathrm{O}_{2}=2 \mathrm{CO}_{2}$

Platinum is employed as the working (and counter) electrode, since it is highly catalytic to CO oxidation and is chemically stable $[9,10]$. The Nafion ${ }^{\circledR}$ thin film solid polymer electrolyte conducts protons and permits the permeation of the gases to the electrodes. AC impedance spectroscopy has been successfully used to characterise such CO sensors, where the proton conducting solid polymer electrolyte is a film of a sulphonated styrene/ethylenebutylene/styrene (S-SEBS) triblock copolymer (DAIS 585, DAIS Corporation) that is recast onto screen-printed electrodes on an alumina substrate [11]. The aim of the research presented here, is to study the AC impedance characteristics, where sensor designs have Nafion ${ }^{\circledR}$ as the solid polymer electrolyte re-cast from solution onto screen-printed electrodes or as the commercial membrane hot-pressed onto a platinum-loaded catalyst cloth. 


\section{Experimental}

Screen-printed electrodes sensor design

Electrodes were screen-printed onto rectangular $(25$ x $10 \mathrm{~mm})$ tiles of alumina, and characterised as described previously for the DAIS 585 polymer electrolyte studies [11]. Nafion ${ }^{\circledR}$ films of different thicknesses were applied by re-casting from a commercial 5.5 w/v\% solution (equivalent weight 1100, prepared from Nafion ${ }^{\circledR} 117$ perfluorinated membrane, Aldrich). The volume of Nafion ${ }^{\circledR}$ solution required in the casting process was calculated by using the area to be covered and assuming a Nafion ${ }^{\circledR}$ density of $2.1 \mathrm{~g} \mathrm{~cm}^{-3}$ [12]. During casting, surface tension was found to affect the uniformity of the films by drawing the solution to the sides of the containment that defined the area to be covered. This was resolved by use of glass reinforced polytetraethylene (PTFE) boundary blocks and a clamp arrangement, which reduced the unfavourable effects of surface tension. Cast Nafion ${ }^{\circledR}$ films were left to dry at room temperature (24 hrs) and then in a desiccator (24 hrs). Optical microscope images at x 200 magnification confirmed that the films had smooth surfaces. Where used, thermal activation took place at $140^{\circ} \mathrm{C}$, following the literature procedure [13]. Atomic force microscopy (AFM) was carried out using an ARIS 3300 personal SPM (Burleigh Instruments).

Sensor design using a commercial Nafion ${ }^{\circledR}$ membrane hot-pressed onto a platinum-loaded catalyst cloth

Sensor fabrication was based on a hot-pressing method for fuel cell applications [14], and involved the use of a Nafion ${ }^{\circledR}$ solution to improve the intimate contact of the catalyst with the membrane. Nafion ${ }^{\circledR} 115$ membrane (Aldrich, equivalent weight 1100, 0.13 mm thick) 
was first cleaned and protonated by boiling in $1 \mathrm{~mol} \mathrm{dm}^{-3}$ sulphuric acid (1 hr) and distilled water (2 hrs), before drying as a flat sheet at room temperature (24 hrs). The platinumloaded catalyst cloth (0.35 mg Pt cm ${ }^{-2}$ from E-Tek Inc.) was cut into three strips (50 x 5 $\mathrm{mm}$ for the counter and reference electrodes and 50 x $10 \mathrm{~mm}$ for the working electrode). Platinum as reference electrode was found to be sufficiently stable for the experiments described here. The membrane and the three strips of catalyst cloth were heated to $80^{\circ} \mathrm{C}$. A sufficient amount of Nafion ${ }^{\circledR}$ solution (5.5 w/v\%, Aldrich) was then sprayed onto the three strips of catalyst cloth to provide a $0.9 \mathrm{mg} \mathrm{cm}^{-2}$ coverage of dry Nafion ${ }^{\circledR}$ coating. The membrane was then placed on the base of a press (Instron Model 4204) and the three strips placed on top in the required configuration and a stainless steel bar with an area of 1.75 $\mathrm{cm}^{2}$ was placed across them. Pressing took place at room temperature for two minutes at a pressure of $0.57 \mathrm{kN} \mathrm{cm}^{-2}$ to give an active working electrode area of $0.50 \mathrm{~cm}^{2}$. In this design, the gases will have access to the electrodes both directly and through the Nafion ${ }^{\circledR}$ membrane.

\section{Design of sensor test rig}

The layout of the sensor testing rig has been described [11]. In summary, the sensing chamber was a glass fibre reinforced polycarbonate box with each sensor being placed on a block of insulating glass-reinforced PTFE in the centre and electrical connections made with silver epoxy contacts. Insulated sockets allowed connection to the electrodes, with holes to accommodate a humidity probe and the gas inlet/outlet pipes. After calibration, the required concentration of $\mathrm{CO}$ was selected by changing the potential applied to the servo of a blender. Prior to the electrochemical measurements, the sensor was positioned in the sensing chamber, and compressed air at $60 \%$ relative humidity was passed (24 hrs) to allow equilibration of the humidity level in the Nafion ${ }^{\circledR}$. 


\section{Electrochemical measurements}

Following stabilisation of the open cell potential (OCP) of a given sensor, cyclic voltammograms (CV's) were recorded at $50 \mathrm{mV} \mathrm{s}^{-1}$ between 0.00 to $+1.00 \mathrm{~V}$ vs. the reference electrode using a Solartron SI 1286 potentiostat with Solartron CorrWare and CorrView software. For AC impedance spectroscopy a Solartron SI 1260 Frequency Response Analyser was used in conjunction with the potentiostat. Following conditioning of a sensor by cyclic voltammetry, when the OCP value had again stabilised, AC impedance scans were carried out at $60 \%$ relative humidity and $22 \pm 2^{\circ} \mathrm{C}$ at the OCP with an AC amplitude of $10 \mathrm{mV}$, generally over a frequency range $60 \mathrm{kHz}$ to $0.1 \mathrm{~Hz}$.

\section{Results and discussion}

Sensors with re-cast Nafion ${ }^{\circledR}$

Figure 1 compares the AC impedance responses (as Nyquist plots), for three sensors with variation in electrode area $\left(0.25,0.37\right.$ and $0.50 \mathrm{~cm}^{2}$; electrolyte thickness $\left.=20 \mu \mathrm{m}\right)$ in a clean air environment. With re-cast Nafion ${ }^{\circledR}$ as electrolyte, a high impedance $\left(10^{7}-10^{8} \Omega\right)$ is observed, which decreases with an increase in electrode area. This sensor design, but prepared by re-casting films of DAIS 585, had earlier given Nyquist plots which could be fitted to a standard equivalent circuit model (Figure 2). The positioning of the two semicircles observed for this model will be defined by the relative values of the bulk electrolyte resistance $\left(R_{\mathrm{b}}\right)$, the capacitance due to the geometry of the electrodes $\left(C_{\mathrm{g}}\right)$, the kinetics of the charge transfer at the interface $\left(R_{\mathrm{ct}}\right)$, the double layer capacitance $\left(C_{\mathrm{dl}}\right)$ and the impedance which exists between the probe (the reference electrode) and the surface of the working electrode $\left(R_{\mathrm{u}}\right)$. With Nafion ${ }^{\circledR}$ as electrolyte, the electrolyte impedance is dominant, and only one enlarged semicircle is observed within the frequency range studied, 
relating to an equivalent circuit with a capacitance $\left(C_{\mathrm{g}}\right)$ in parallel with a resistance $\left(R_{\mathrm{b}}\right)$. On addition of 30\% CO at 1 atmosphere to the sensing chamber, only a slight increase in the semicircle was observed, which now fell across the x-axis at a higher Z' value. This limited response corroborated CV measurements, where for these high impedance systems, no CO oxidation current could be measured above the current in clean air.

Figure 3 compares the AC impedance responses (as Nyquist plots), for three sensors with variation in electrolyte thickness $\left(70,50,20 \mu \mathrm{m}\right.$; electrode area $\left.=0.37 \mathrm{~cm}^{2}\right)$ in a clean air environment. As the thickness of the electrolyte layer is increased, the semicircle becomes enlarged, indicating a further increase in impedance. This was again corroborated by CV measurements, which were dominated by an 'Ohm's law' response, showing that the resistance of the systems increased as the electrolyte film thickness increased, due to the likely poorer continuity of the thicker films.

Thermal activation/re-hydration of the re-cast Nafion ${ }^{\circledR}$ films caused the impedance of the sensor system to decrease a hundredfold. AFM images of Nafion ${ }^{\circledR}$ films (Figure 4), before and after thermal activation, showed clusters and cavities of various sizes. Prior to the heating process (Figure 4a), the clusters were in the region of $1.6 \mu \mathrm{m}$ across. After thermal activation (Figure 4b), the clusters amalgamated, giving an average cluster size of $3.1 \mu \mathrm{m}$. This apparent change in the structure is due to thermal annealing above the glass transition temperature (for Nafion ${ }^{\circledR}-\mathrm{H}, T_{\mathrm{g}}=110^{\circ} \mathrm{C}[15]$ ) of the polymer, giving rise to re-orientation of the side chains and improved connectivity throughout the polymer film.

Sensors with catalyst loaded cloth pressed onto Nafion ${ }^{\circledR}$ membrane

Sensors prepared by hot-pressing $0.35 \mathrm{mg} \mathrm{Pt} \mathrm{cm}^{-2}$ loaded catalyst cloth (E-TEK Inc.) onto a Nafion ${ }^{\circledR} 115$ membrane produced a system with a much lower impedance $\left(<10^{3} \Omega\right)$ 
(Figure 5). Nyquist plots gave a flattened semi-circle at high frequencies (due to $C_{\mathrm{g}}$ and $R_{\mathrm{b}}$ in parallel), followed by the start of a large semicircle (due to the double-layer capacitance, $C_{\mathrm{dl}}$, in parallel with the charge-transfer resistance, $R_{\mathrm{ct}}$ ) over a lower frequency range. This follows the equivalent circuit elements predicted (Figure 2) for an electrode covered with a polymer film $[16,17]$ and found for a commercially available Nafion ${ }^{\circledR} 117$ membrane over the frequency range $100 \mathrm{MHz}$ to $10 \mathrm{~Hz}$ [18]. When $\mathrm{CO}$ was present the lower frequency range semi-circle on the Nyquist plot was pulled down towards the $Z^{\prime}$ axis, indicating that the interfacial impedance of the electrochemical system had decreased (Figure 6). Although small, the AC interrogative wave $(10 \mathrm{mV})$ appears sufficient to induce local polarisation to allow some oxidation of chemisorbed $\mathrm{CO}$ on the platinum working electrode, affecting both the double layer capacitance $\left(C_{\mathrm{dl}}\right)$ and the kinetics of charge transfer at the interface $\left(R_{\mathrm{ct}}\right)$ due to a perturbation of the local current. Adsorbed CO on the surface of the Pt catalyst, will introduce charge carriers to the dielectric, therefore increasing the conductivity at that interface. If charge carriers are present then this would explain the relatively small decrease observed in the electrolyte impedance ( $R_{\mathrm{ct}}$ and $\left.C_{\mathrm{dl}}\right)$.

\section{Conclusions}

AC impedance spectroscopy has been shown to be useful for the characterisation of CO sensors, where Nafion ${ }^{\circledR}$ is used as the solid polymer electrolyte. For a re-cast Nafion ${ }^{\circledR}$ sensor design, the Nyquist plots are dominated by the electrolyte impedance and such sensors do not respond to CO. A second circular arc, corresponding to the interfacial impedance, was not observed, unlike this sensor design where a film of a sulphonated styrene/ethylene-butylene/styrene (S-SEBS) triblock copolymer is the solid polymer electrolyte [11]. A sensor design using a commercial Nafion ${ }^{\circledR}$ membrane produced a 
system with a much lower impedance, Nyquist plots showing a flattened semi-circle at high frequencies, followed by the start of a large semi-circle, which was responsive to CO.

\section{Acknowledgements}

We thank Loughborough University and BG Technology for support.

\section{References}

[1] T. Otagawa, M. Madou, S. Wing, J. Rich-Alexander, S. Kusanagi, T. Fujioka, A. Yasuda, Sens. Actuators, B, Chem. 1 (1990) 319.

[2] A. Yasuda, N. Yamaga, K. Doi, T. Fujioka, S. Kusanagi, Solid State Ionics 40/41 (1990) 476.

[3] A. Yasuda, T. Fujioka, N. Yamaga, S. Kusanagi, Reactive Polymers 15 (1991) 203.

[4] A. Yasuda, N. Yamaga, K. Doi, T. Fujioka, S. Kusanagi, J. Electrochem. Soc. 139 (1992) 1091.

[5] A. Yasuda, K. Doi, N. Yamaga, T. Fujioka, S. Kusanagi, J. Electrochem. Soc. 139 (1992) 3224.

[6] A. Yasuda, N. Yamaga, K. Doi, T. Fujioka, S. Kusanagi, J. Electroanal. Chem. 354 (1993) 39.

[7] A. Yasuda, N. Yamaga, K. Doi, T. Fujioka, Sens. Actuators, B, Chem. 21 (1994) 229.

[8] P.D. van der Wal, N.F. de Rooij, M. Koudelka-Hep, Sens. Actuators, B, Chem. 35-36 (1996) 119. 
[9] H. Muraki, S. Matunaga, H. Shinjoh, M.S. Wainwright, D.L. Trimm, J. Chem. Tech. Biotechnol. 52 (1991) 415.

[10] S.A. Bilmes, A.J. Arvia, J. Electroanal. Chem. 361 (1993) 159.

[11] R.J. Mortimer, A. Beech, J. Electrochem. Soc. 147 (2000) 780.

[12] R.S. Yeo, Polymer 21 (1980) 432.

[13] L.A. Zook, J. Leddy, Anal. Chem. 68 (1996) 3793.

[14] F.N. Büchi, G.G. Scherer, J. Electroanal. Chem. 404 (1996) 37.

[15] S.C. Yeo, A. Eisenberg, J. Appl. Polym. Sci. 21 (1977) 875.

[16] J.R. Owen, in: R.G. Linford, (Ed.), Electrochemical Science and Technology of Polymers 1, Elsevier Science Publishers Ltd., London and New York, 1987, Ch. 3, pp. 45 66.

[17] R.G. Linford, in: R.G. Linford, (Ed.), Electrochemical Science and Technology of Polymers 2, Elsevier Science Publishers Ltd., London and New York, 1990, Ch. 7, pp. 281 $-318$.

[18] R.S. Chen, P.E. Stallworth, S.G. Greenbaum, J.J. Fontanella, M.C. Wintersgill, Electrochim. Acta 40 (1995) 309. 
Figure Captions

Fig. 1

Nyquist plots for sensors with variation in electrode area, (a) $\left(0.25 \mathrm{~cm}^{2}\right.$, electrolyte thickness $=20 \mu \mathrm{m}),(\mathrm{b})\left(0.37 \mathrm{~cm}^{2}\right.$, electrolyte thickness $\left.=20 \mu \mathrm{m}\right)$ and $(\mathrm{c})\left(0.50 \mathrm{~cm}^{2}\right.$, electrolyte thickness $=20 \mu \mathrm{m})$ in a clean air environment $(60 \%$ relative humidity and $22 \pm 2^{\circ} \mathrm{C}$ ). All plots were measured between $60 \mathrm{kHz}$ and $0.1 \mathrm{~Hz}$.

Fig. 2

Equivalent circuit model and predicted AC impedance plot. $R_{\mathrm{u}}$ is the uncompensated resistance between the probe (the reference electrode) and the working electrode surface.

Fig. 3

Nyquist plots for sensors with variation in electrolyte thickness, (a) (70 $\mu \mathrm{m}$, electrode area $\left.=0.37 \mathrm{~cm}^{2}\right),(\mathrm{b})\left(50 \mu \mathrm{m}\right.$, electrode area $\left.=0.37 \mathrm{~cm}^{2}\right)$ and $(\mathrm{c})(20 \mu \mathrm{m}$, electrode area $=0.37$ $\left.\mathrm{cm}^{2}\right)$ in a clean air environment $\left(60 \%\right.$ relative humidity and $\left.22 \pm 2^{\circ} \mathrm{C}\right)$. All plots were measured between $60 \mathrm{kHz}$ and $0.1 \mathrm{~Hz}$.

Fig. 4

AFM images of a sample (35 x $35 \mu \mathrm{m}$ area) of cast Nafion ${ }^{\circledR}$ solid polymer electrolyte, before (a) and after (b) thermal activation.

Fig. 5

Nyquist plots indicating the response of an E-TEK/Nafion ${ }^{\circledR}$ sensor in a clean air environment $\left(60 \%\right.$ relative humidity and $\left.22 \pm 2^{\circ} \mathrm{C}\right)$. The plot was measured between $10 \mathrm{kHz}$ and $0.003 \mathrm{~Hz}$.

Fig. 6 
Nyquist plots indicating the response of an E-TEK/Nafion ${ }^{\circledR}$ sensor in a clean air environment (a) and in the presence of 100 (b), 200 (c), 500 (d) and 1000 (e) ppm CO (60\% relative humidity and $22 \pm 2^{\circ} \mathrm{C}$ ). All plots were measured between $60 \mathrm{kHz}$ and 0.1 Hz. 
Figure 1

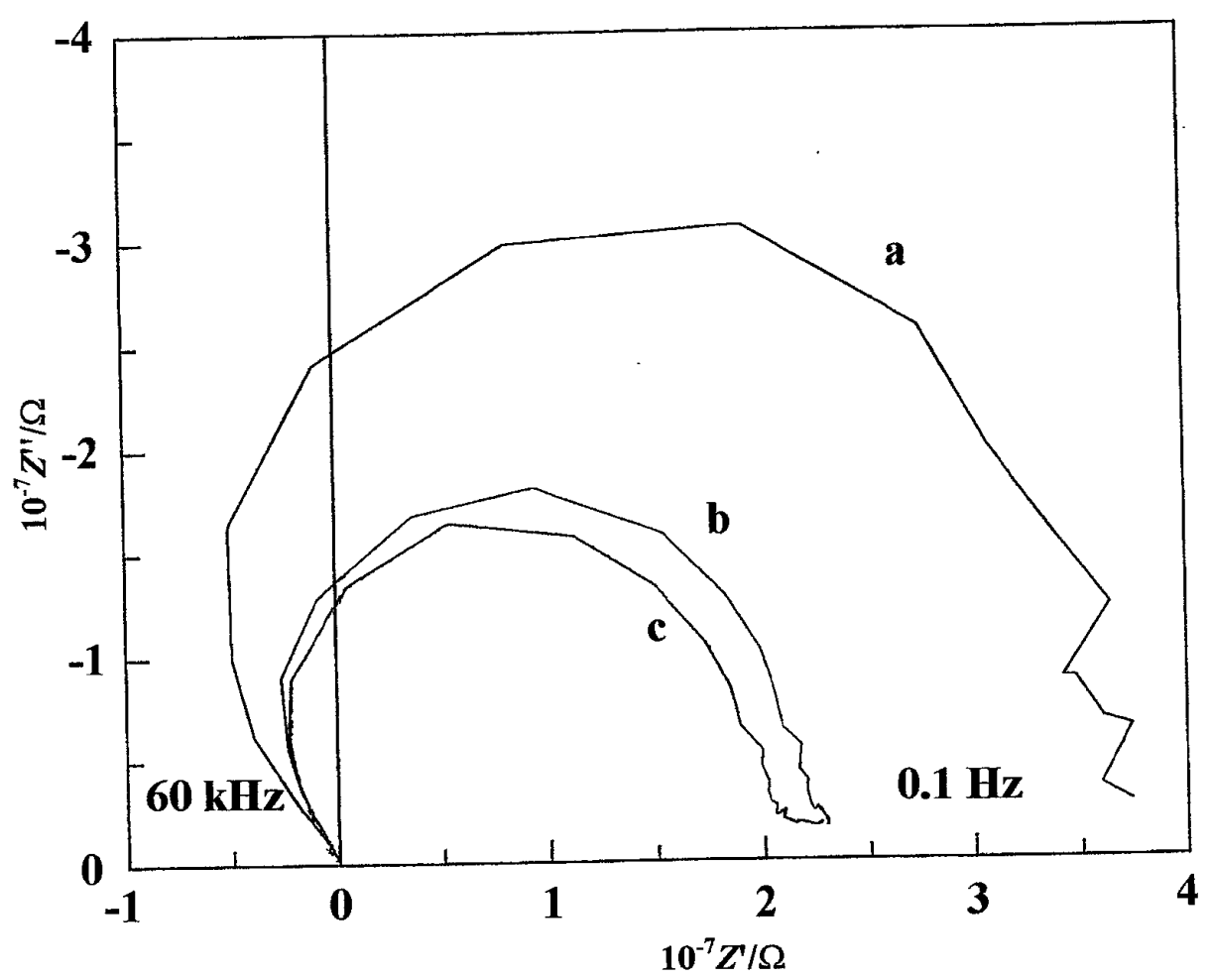


Figure 2
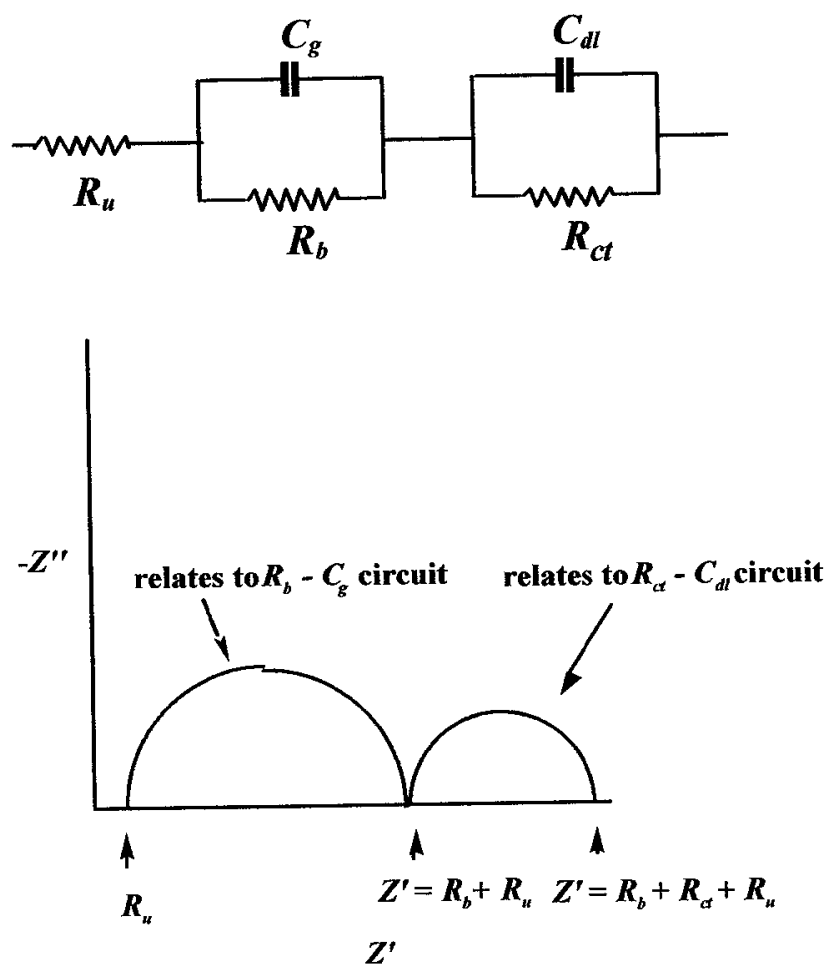
Figure 3

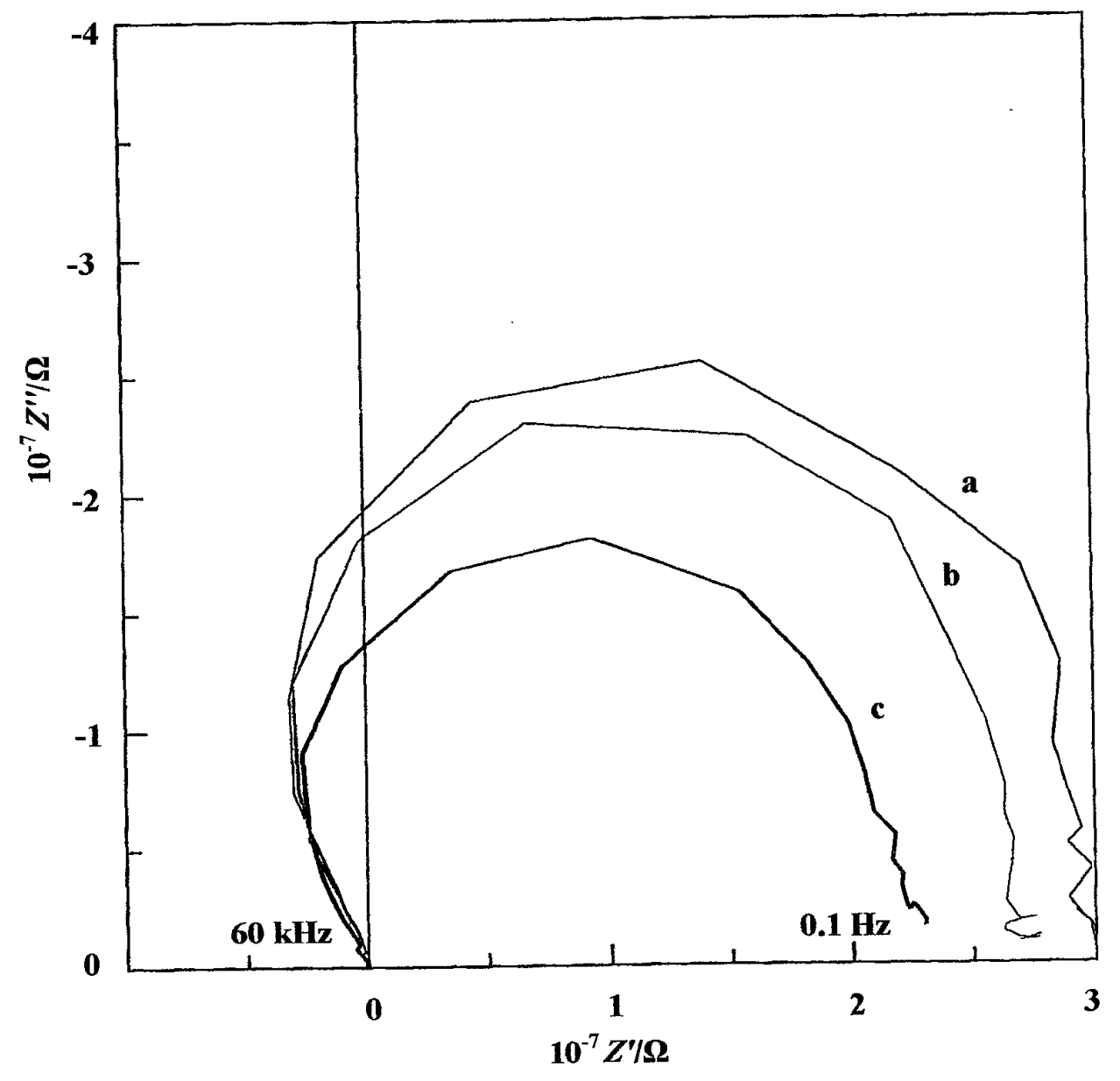


Original Figure 4 - relabel as Figure 5

Figure 4

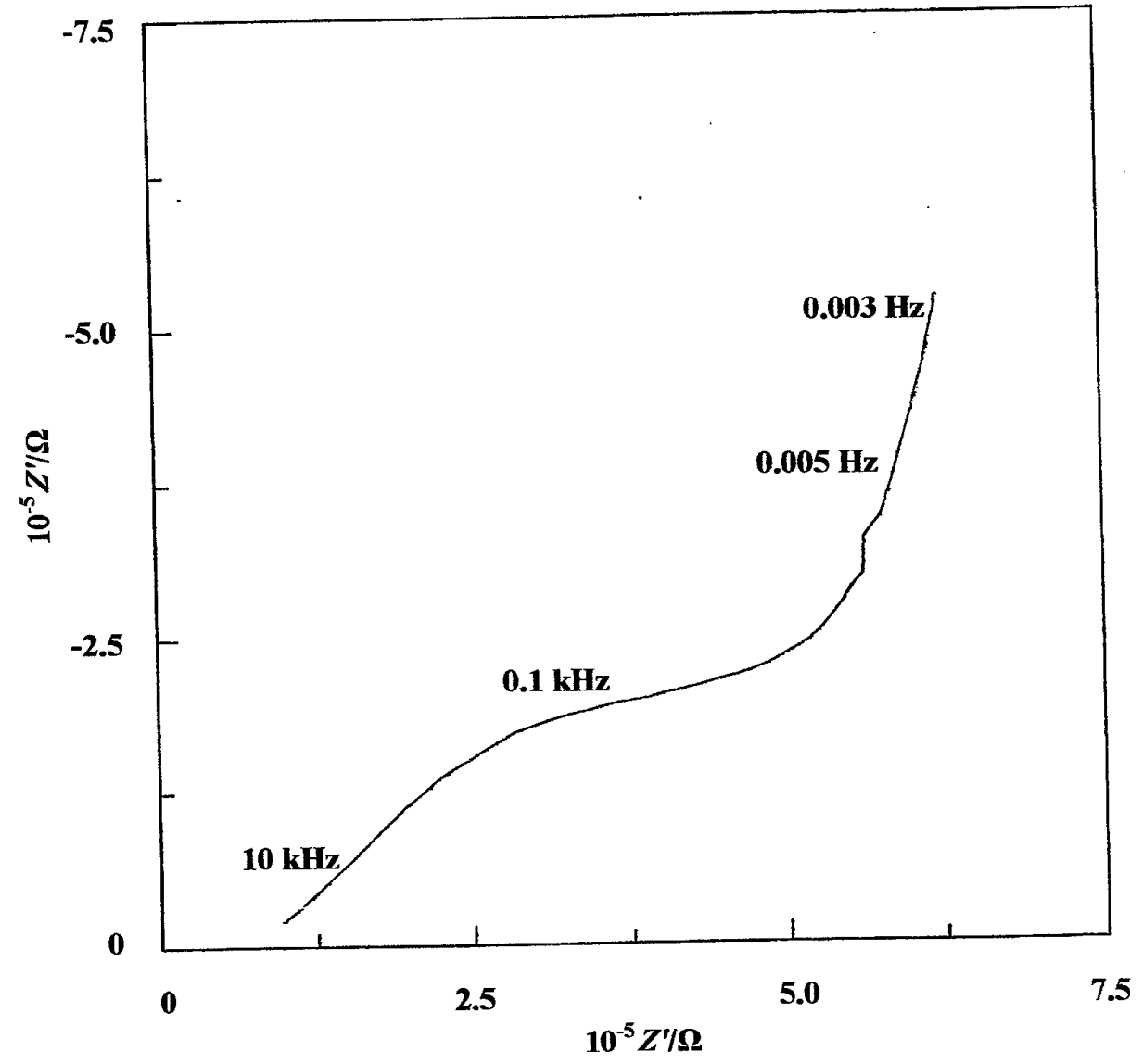


Original Figure 5 - relabel as Figure 6

Figure 5

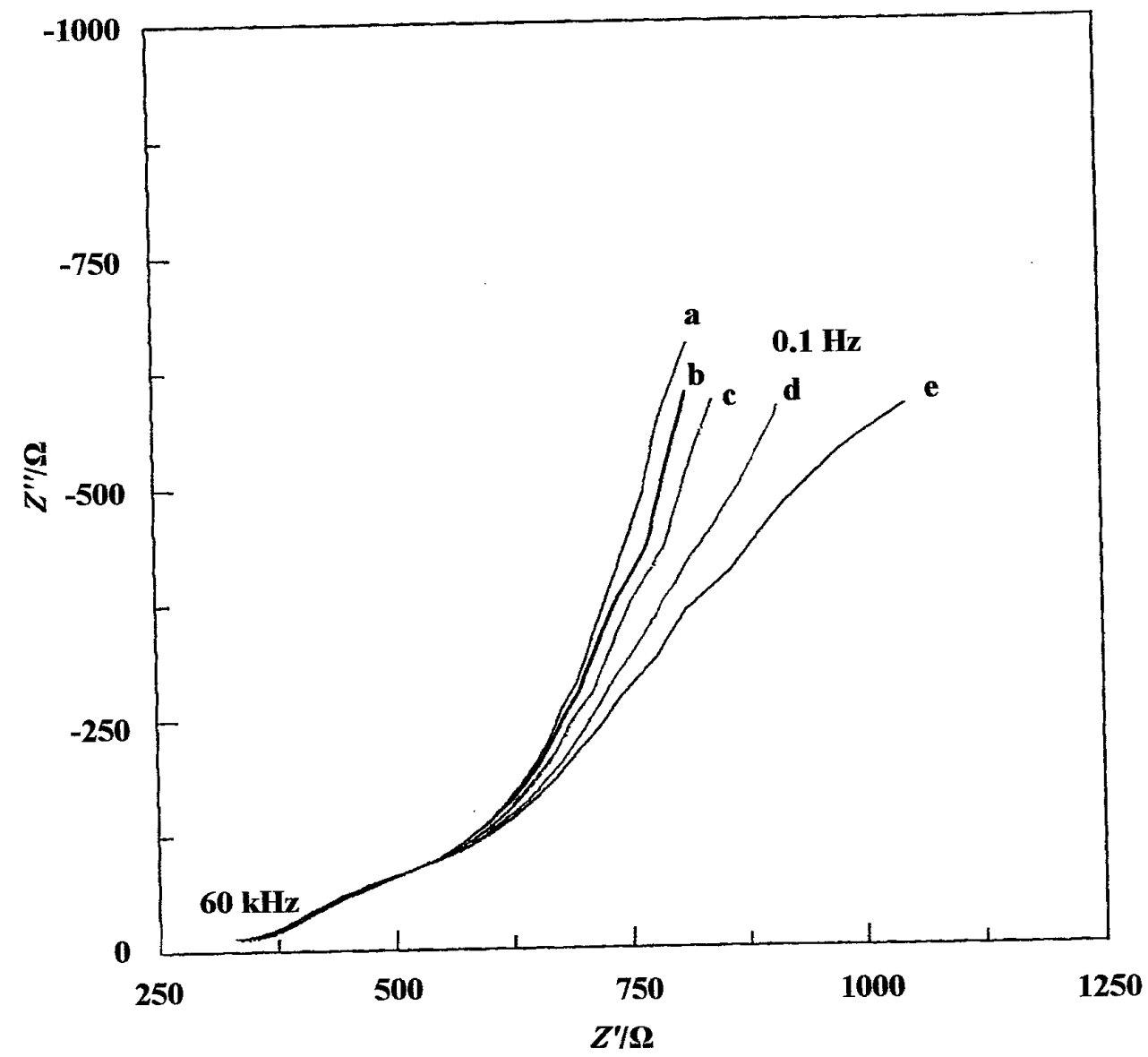

